\title{
Results of using different breed studs in commercial fine wool sheep breeding
}

\author{
Vasily Aboneev ${ }^{1, *}$, Dmitry Aboneev ${ }^{2}$, Ekaterina Aboneeva ${ }^{2}$, Safarbi Kazanchev ${ }^{3}$, and \\ Dastanbek Baimukanov ${ }^{4}$ \\ ${ }^{1}$ FSBSI Krasnodar Scientific Center for Animal Science and Veterinary Medicine, 4, Pervomaiskaya \\ Str., 350055 Krasnodar, Russia \\ ${ }^{2}$ North Caucasian Federal University, 1, Pushkina Str., 355017 Stavropol, Russia \\ ${ }^{3}$ Kabardino-Balkarian State Agricultural University named after V.M. Kokov, Lenin Avenue, 1V, \\ 360030 Nalchik, Russia \\ ${ }^{4}$ Kazakh National Agrarian Research University, 8, Abai Avenue, 050010 Almaty, Republic of \\ Kazakhstan
}

\begin{abstract}
This work presents the material of research and production experiments on the crossing of stud rams of the North Caucasian meat and wool breed and Australian meat merino with fine wool ewes of a commercial herd. It is identified that the use of North Caucasian rams on fine wool ewes serves to increase the fertilizing ability and milk production of the breeding stock, to increase viability and resistance of young animals, as confirmed by the best morphometrical differences of crossbred offspring placentas. Crossbred offspring from semi-fine wool rams had a large live weight at birth at 21 days and at 4 months of age. The use of Australian producers did not have a significant effect on the above indicators of economically useful traits in comparison with purebred breeding.
\end{abstract}

\section{Introduction}

One of the most important tasks in the development of the current industry is to increase the competitiveness of sheep breeding production. Changes in the contemporary social and economic conditions and, as a result, a decrease in the demand for most of the products of sheep breeding led to a sharp decrease in the number of animals, their productivity, a change in the breed composition and structure of breeds of different directions. Nevertheless, the main types of fine wool sheep products, wool and meat, have not lost their value, while their value has changed in the direction of mutton meat. This type of product was of the utmost importance at all stages of the industry's development. Specifically, in the period from 1985 to 2005, new types of sheep with improved indicators of meat production were bred in commercial fine wool herds. The development of techniques and methods for increasing the fertilizing ability, ewes fertility, resistance and viability of young animals, especially in the first periods of an animal's life, including

\footnotetext{
*Corresponding author: aboneev49@mail.ru
} 
before separation from mothers is an important element contributing to an increase in the production of mutton meat. The study of these issues is the main objective of our research.

\section{Materials and Methods}

To achieve the objectives, reproductive qualities of Caucasian breed ewes were identified when they were crossed with North Caucasian meat and wool rams (group 1), Australian meat merino rams (group 2) and purebred Caucasian studs (group 3), as well as some indicators of productivity, resistance and viability of offspring of different origin. To do this, the flock of fine wool ewes of the senior shepherd of agricultural enterprise "Novomaryevskoe" M.M. Magomedov in the amount of 425 animals was inseminated by rams of the above breeds in approximately the same amount by the method of their daily sampling in the hunt. In the first group 140 animals were inseminated, in the second group 130 animals and in the third group - 155 animals. At the same time, the reproductive qualities of rams and ewes, viability, resistance and live weight of the produced offspring, including some morphometrical differences of the placenta were studied. To achieve the objective, the volume and quality of sperm production of stud rams of different breeds, the fertility of mothers by the number of lambs per 100 lambed ewes, the mortality of lambs and their live weight from birth to 4 months of age, some morphometric differences of the placenta, blood serum bactericidal (SBA) and lysozyme (SLA) activity, according to existing zootechnical and biological methods. The feeding level of ewes, stud rams and the produced offspring corresponded to the set norms.

\section{Results and Discussion}

Two-year-old studs, which met the economically useful requirements of the elite class and had features typical to the breeds listed above were selected from the existing stud ram flock to carry out research and production experiments. Fresh semen of Australian meat merino was imported from the Stavropol Research Institute of Livestock and Fodder Production experimental station. The volume of ejaculate in the Caucasian breed was 1.42 $\mathrm{ml}$, with a mobility of 9.5 points, and in the North Caucasian breed and Australian meat merino these indicators were $1.53 \mathrm{ml}, 9.5$ points and $1.12 \mathrm{ml}, 9.0$ points accordingly.

An important biological peculiarity of different breeds of sheep, which significantly affects the economic efficiency and the overall profitability of the industry, is the fertility of the ewes and the viability of the produced offspring. Scientists [2, 4, 5, 6-11] pointed out that the fertility of ewes and the viability of young animals can be increased with different methods, including targeted selection of multiple ewes and rams, as well as interbreeding of sheep of different productivity directions. They also pointed out that ewes with twins and triplets produced more meat in body weight and teg of finer assortments than ewes with single lamb, despite the lower average weight of each lamb.

Our experimental studies on the individual accounting of the results of insemination and lambing of fine wool ewes inseminated with the sperm of rams of different breeds showed significant differences between the compared animals, including the resulted offspring.

Table 1 shows information on fertilization rate, ewe reproduction capability, viability and live weight of young animals. 
Table 1. Reproductive qualities of ewes, viability and live weight of lambs.

\begin{tabular}{|l|c|c|c|}
\hline \multirow{2}{*}{ Indicators } & \multicolumn{3}{|c|}{ Group } \\
\cline { 2 - 4 } & $\mathbf{1}$ & $\mathbf{2}$ & $\mathbf{3}$ \\
\hline Inseminated ewes, animals & 140 & 130 & 155 \\
\hline Lambed ewes, animals & 134 & 119 & 142 \\
\hline \multicolumn{1}{|c|}{$\%$} & 95.9 & 91.2 & 91.5 \\
\hline Total lambs produced, animals & 152 & 123 & 147 \\
\hline Reproduction capability, \% & 114.0 & 103.3 & 103.7 \\
\hline Lamb viability up to 4 months, animals & 142 & 110 & 132 \\
\hline \multicolumn{1}{|c}{$\%$} & 93.4 & 89.6 & 88.9 \\
\hline Live weight of young ewe, kg at birth & $4.2 \pm 0.10$ & $3.8 \pm 0.08$ & $3.8 \pm 0.07$ \\
on day 21 & $11.8 \pm 0.16$ & $10.9 \pm 0.15$ & $10.7 \pm 0.14$ \\
at 4 months & $24.1 \pm 0.19$ & $21.9 \pm 0.19$ & $21.5 \pm 0.19$ \\
& & & \\
\hline
\end{tabular}

The analysis of the information from Table 1 indicates that the ewes inseminated by the North Caucasian rams had the best fertilizing ability, and somewhat worse was this indicator by the Caucasian and Australian meat merinos. At the same time, 30 animals or $19.4 \%$ of the ewes, inseminated in the first hunt by rams of the Australian meat merino, remained barren and were re-inseminated by the rams of the same group. 5 ewes from rams of the North Caucasian breed and purebred Caucasian studs, or $3.6 \%$ and $3.8 \%$, respectively remained barren. The fertility of ewes of the compared groups was $114.0 \%$ in 1 st group, and in 2nd and 3rd groups $103.3 \%$ and $103.7 \%$, respectively, that is, the ewes of 1 st group prevailed over the peers of 2 nd and 3rd groups by $11.3 \%$ and $11.7 \%$.

An important indicator that determines the efficiency of the breeding process and the profitability of the sheep breeding industry is the resistance of the produced offspring and its subsequent viability. The resistance is caused by complex protective reactions of the body and ensures the viability of young sheep of different genotypes in postnatal ontogenesis $[1,2,10,12,13,14]$.

In our studies, the estimation of the protective potential of the experimental groups of animals was carried out by monitoring the activity of humoral factors (serum bactericidal activity - SBA, serum lysozyme activity - SLA).

The analysis of obtained results, shown in Table 2, made it possible to indicate a number of patterns due not only to the age characteristics of the produced offspring, but also due to their breed.

Experimental lambs in the early postnatal period had the lowest rates of humoral immunity. At birth, the level of serum bactericidal and lysozyme activity (SBA, SLA) in young animals of different origins varied from $35.94 \%$ to $37.10 \%$ and from $22.26 \%$ to $23.71 \%$. At the same time, SBA indicators were higher in the crossbred offspring of North Caucasian rams by 0.78 abs.\% and 1.16 abs.\% related to the peers of 2 nd and 3 rd groups. According to the level of blood serum lysozyme activity, the lambs of the 1st group prevailed over the animals of the 2 nd and 3rd groups. The difference reached 0.23 abs.\% and 1.45 abs. $\%$ in favor of the offspring of 1 st group, respectively. By the age of two months, there was an increase in indicators on the protective potential of the experimental animals (Table 2). It can be assumed that a sharp increase in the level of blood serum bactericidal activity in lambs of the experimental groups in this age period relates to the gradual formation, development of the immune system, which provides the protective potential of the growing organism, as evidenced by the indicators of the growth rate of young animals. At the same time, an increase in bactericidal activity was higher in the offspring of North Caucasian rams related to the lambs of 1st and 3rd groups. Referring to the level of blood serum lysozyme activity, no significant differences were found between the experimental groups in this indicator of humoral immunity in the studied period of ontogenesis. 
Table 2. Age dynamics of the natural resistance level of young ewes of different genotypes, $\%$

\begin{tabular}{|c|c|c|c|c|}
\hline \multirow{2}{*}{ Indicator } & \multirow{2}{*}{ Age periods } & \multicolumn{3}{|c|}{ Group } \\
\cline { 2 - 5 } & & $\mathbf{1}$ & $\mathbf{2}$ & $\mathbf{3}$ \\
\hline \multirow{3}{*}{ SBA } & At birth & $37.10 \pm 0.83$ & $36.32 \pm 0.70$ & $35.94 \pm 0.83$ \\
\cline { 2 - 5 } & 2 months & $55.57 \pm 0.78$ & $55.01 \pm 0.84$ & $54.37 \pm 0.87$ \\
\cline { 2 - 5 } & 4 months & $46.72 \pm 0.51$ & $46.09 \pm 0.86$ & $45.71 \pm 0.36$ \\
\hline \multirow{3}{*}{ SLA } & At birth & $23.71 \pm 1.06$ & $23.48 \pm 0.77$ & $22.26 \pm 0.93$ \\
\cline { 2 - 5 } & 2 months & $24.75 \pm 0.61$ & $24.62 \pm 0.59$ & $24.06 \pm 0.62$ \\
\cline { 2 - 5 } & 4 months & $37.74 \pm 0.47$ & $37.06 \pm 0.92$ & $36.43 \pm 0.47$ \\
\hline
\end{tabular}

The reactivity of the organism gradually improves with an increase in the age of young animals in the experimental groups and by the age of 4 months a decrease in the serum bactericidal activity and an increase in lysozyme activity are observed.

For a specific tendency of age-related changes in the indices of natural resistance in the experimental young lambs, the superiority of the offspring of North Caucasian rams over the peers of young lambs of 2nd and 3rd groups in terms of the level of activity of humoral factors (SBA, SLA) was revealed. At the age of 4 months, this advantage in favor of the young lambs of 1 st group was 1.4 abs.\% and 2.2 abs.\% in bactericidal activity and 1.8 abs. $\%$ and 3.6 abs. $\%$ in lysozyme activity.

Consequently, a comparative analysis of the results obtained revealed the advantage of the organism protective potential of the offspring of semi-fine wool rams of the North Caucasian meat and wool breed in all periods of postnatal ontogenesis over animals of other variants of selection according to the level of humoral factors of natural defense. At the same time, the amplitude of the revealed changes was within the physiological norm.

The best protective properties of the offspring of the compared groups had a certain effect on the viability of young animals from birth to the separation from ewes. It is one of the major indicators that determine the economic efficiency of the industry. In our studies, the offspring produced by North Caucasian rams turned out to be the most viable from birth to the separation. This indicator reached $93.4 \%$, which is $3.8 \%$ and $4.5 \%$ more than in animals of 2 nd and 3 rd groups.

Sampled placentas, 8 from each ewe, incident with rams of different breeds, were subjected to laboratory studies to determine some morphometrical indicators. It was identified that the weight of the placenta from the ewes of the first group was equal on average to $276 \mathrm{~g}$, while in animals of the second and third groups it was, respectively, $245 \mathrm{~g}$ and $234 \mathrm{~g}$, or 12.7 and 17.9 percent less. The measurement of the cotyledon number in the placenta of the ewes of the compared groups made it possible to identified the following patterns. While the ewes inseminated by the North Caucasian rams had 76.7 cotyledons, the peers of the 2nd and 3rd groups had 5.5 and 6.5 less, or $7.7 \%$ and $9.3 \%$. Significant differences were also found in the size of cotyledons in the placenta of the ewes of the compared groups. Thus, the size of cotyledons in the placenta of ewes inseminated by semifine wool rams of the North Caucasian breed was $2.2 / 3.1 \mathrm{~cm}$, and for ewes of 2 nd group, this indicator was $1.8 / 2.2 \mathrm{~cm}$. According to this indicator the ewes of the 3rd group are in the last place. The size of their cotyledons was $1.6 / 2.0 \mathrm{~cm}$. The distance between cotyledons in animals of 1st, 2nd, 3rd groups was $1.8 / 3.1 \mathrm{~cm} ; 2.9 / 3.7 \mathrm{~cm}$ and $3.2 / 4.3 \mathrm{~cm}$, respectively. These results indicate that the density of cotyledons in the placenta of crossbred young ewes from North Caucasian rams is much higher related to the peers of 2nd and 3rd groups, which means that the efficiency of fetal nutrition in this group of animals was higher. The observed patterns indicate that the insemination of ewes by rams of the North Caucasian meat and wool breed during the period of pregnancy contributes to the better development of the placenta, and as a result, better development of its offspring during the period of embryonic development. It is confirmed by our experimental data. 
Individual weighing of lambs at birth (Table 1) showed that the lambs produced by the ewes of the 1st group in live weight exceeded the peers of the 2nd and 3rd groups by $0.4 \mathrm{~kg}$ or $10.5 \%(\mathrm{P}>0.05)$. The milk production of the ewes, calculated as the product of the average live weight of the lambs at the age of 21 days plus the coefficient 5 , was the highest in the animals of the first group. This advantage over the ewes of 2 nd and 3 rd groups was $8.3 \%$ and $10.2 \%$, respectively, $(\mathrm{P}>0.05)$. Weighing of lambs when separating from ewes showed a similar pattern between the compared groups of animals. If the average live weight of the lambs of the first group was $24.1 \mathrm{~kg}$, then in the offspring of the second and third groups it was $2.2 \mathrm{~kg}$ and $2.6 \mathrm{~kg}$ less, or $10.0 \%$ and $12.1 \%(\mathrm{P}>0.05)$

The calculation of economic efficiency indicators based on the methodology of scientists (3) showed that, with the higher fertility of ewes, the viability and live weight of lambs in the first group of animals, the level of profitability was $20.3 \%$ and $21.7 \%$ higher, related to the offspring of 2 nd and 3 rd groups.

\section{Conclusion}

Consequently, the use of stud rams of the North Caucasian meat and wool breed in commercial fine wool sheep breeding allows to increase the fertility and milk production of ewes, the viability, live weight of offspring and the profitability of young-stock breeding in comparison with the use of Australian meat merino and purebred breeding.

\section{References}

1. V. V. Aboneev, L. N. Skorykh, Sheep, Goats, Woolen Business, 3, 20-22 (2002)

2. V. V. Aboneev, A. I. Surov, K. G. Chukhno, Zootechniya, 8, 26-27 (2008)

3. V. V. Aboneev, N.K. Tymoshenko, T.P. Rusanova et al., Methodology for calculating the economic efficiency of the production of sheep products in order to more fully realize the economic potential of the industry (2013)

4. V. V. Aboneev, V. V. Marchenko, R. P. Larionov, Problems of Livestock and Fodder Production in Russia, 14-17 (2015)

5. V. V. Aboneev, L. G. Gorkovenko, A. Ya. Kulikova, N. I. Tsapkina, Scientific basis for increasing the productivity of farm animals, 2, 4-9 (2016)

6. V. V. Aboneev, V. V. Marchenko, L. A. Gnezdilova, N. I. Tsapkina, International bulletin of Veterinary Medicine, 2, 35-42 (2017)

7. V. V. Aboneev, L. A. Gnezdilova, V. T. Ranyuk, D. V. Aboneev, Veterinary Medicine, Animal Science and Biotechnology, 1, 120-125 (2019)

8. V. V. Aboneev, T. T. Tarchokov, S. F. Sukhanova, D. V. Aboneev, E. V. Aboneeva, V. V. Marchenko, IOP Conf. Series: Earth and Environmental Science, 341 (2019) 012045

9. L. A. Gnezdilova, V. V. Aboneev, D. V. Aboneev, Current state, problems and prospects for the development of agricultural science, 275-276 (2018)

10. A. A. Erokhin, V. V. Aboneev, E. A. Karasev, S. A. Erokhin, D. V. Aboneev, Forecasting the productivity, reproduction and resistance of sheep (2010)

11. Yu. A. Kolosov, I. S. Gubanov, V. V. Aboneev, Izvestiya Orenburskogo SAU, 4(72), 310-312 (2018)

12. Y. Kolosov, A. Klimenko, V. Vasilenko, N. Shirokova, L. Getmantseva, A. Kolosov, V. Aboneev, L. Chizhova, V. Marchenko, A. Mikhailenko, D. Aboneev, OnLine Journal of Biological Sciences, 17(4), 343-347 (2017) 
13. L. N. Chizhova, V. V. Aboneev, S.N. Shumaenko, Sheep, Goats, Woolen Business, 4, 13-15 (2014)

14. L. N. Chizhova, V. V. Aboneev, D. V. Aboneev, Proceedings of the international research conference, 143-146 (2014) 